\title{
CAUSES OF DIFFERENT PROFITABILITY OF AGRICULTURAL SECTOR
}

\author{
Branko Vučković ${ }^{1}$
}

\section{Summary}

This work involves identification of causes of different profitability of agricultural sector done on case study of nearly identical agricultural enterprises. It shows that financial mix even in scope of similar companies can lead to various profit indicators. Through comparative financial analysis in the same industry and activity by applying methods and techniques we have concluded that company PP Ratkovo operates more stable and closer to determined norms and also shows better results in majority of the indicators. Horizontal and vertical analysis indicates that companies in Agribusiness partner group use expensive external sources of financing. We have precisely defined in which cost segment occurs highest distinction. Also we have shown reasons why PP Ratkovo in the last two years manifests great profitability measured by ebit, ebitda and net profit as well as excellent structure of material costs and wages costs in in frame of the operating income, and reasons why enterprises in Agribusiness partner group does not.

Key words: Profitability, Agricultural sector, Financial analysis

JEL: $Q 14$

\section{Introduction}

Determine the reasons of diverse profitability of similar agricultural enterprises primary agricultural production filed in APR under the group 0111 Cultivation of wheat (except rice), legumes and oilseeds, medium size, which have similar arable land and which operate on same limited geographic area. PP Sombor ad area 1600 hectare, Bački Brestovac, PP Vojvodina ad 1400 hectare, Srpski Miletić, PP Miletić ad 1400 hectare, Feketić PP Feketić ad 1050 hectare, which are enterprises of one owner and Ratkovo, PP Ratkovo doo 2000 hectare, which is enterprise of other owner. Many authors claim that diversity is among the most important predictors of a company's sales revenue, customer numbers and profitability. On the other side, in the primary agricultural

1 M.A. Branko Vučković, Vojvodjanska Banka NBG Group, Director of North Vojvodina Business Centre, Banatska Street no. 24, 25000 Sombor, Phone : +381 648960025 , E-mail: vule.sombor@gmail.com 
sector is difficult to create and maintain diversity, due to its very specific characteristic. Primary agriculture and agriculture in general, is inflexible, supply is inelastic in the short run, supply is influenced by weather (climate conditions), risk is significant, and access to financial services is limited (due to insufficient collateral, in most cases). In that context, identification of the reasons and consequences of diverse profitability in this sector is that what makes this research a challenge.

Research goal is to show through comparative analysis of financial results presented in Balance Sheet and Income Statement problems and ways of noticing problem as well as overcome them in enterprises which financial indicators deviate from the prescribed and recognized norms, or indicators of other similar enterprises. When comparing changes in the company's ratios from period to period, we can point improvements in performance or developing problem areas. In that context, we define assumptions for better and more successful business implementation and profit increase as one of the basic category in modern business. In our research we have also given conclusions which can achieve that. Considering definition of the problem and research goal for starting hypothesis we are taking that each enterprise which has negative results in their financial reports compared to the prescribed and recognized norms or other enterprises definitely has disorder in financial flows which reflects on overall success (or failure) of the enterprise. By locating those problems we can improve financial results of the business that operate below the average.

H1 (general hypothesis): Financial analysis is an important part of the decision making process in agriculture.

$\mathrm{H} 2$ (partial hypothesis): Interpretation of the results of financial analysis is only possible in the proper context (it is necessary to take into account the specific characteristics of agriculture).

H3 (partial hypothesis): Financial analysis in agriculture has limits - simply manipulation of historical data can hide the actual state of the agricultural company.

During research we have used methods of analysis, methods of synthesis, statistical methods and case study. Foundation of our research is based on method of partition and comparison. We have dismembered sheets of given enterprises on basic categories which we observed in timeline of 5 previous years and compared indicators in that period. Method of comparison which we used is based on comparison of four very similar enterprises of single owner with the enterprise of another owner. All enterprises have similar characteristic of agricultural goods, and all were privatized in same period in similar way; thus we have unified material with representable comparison of all financial indicators. We have done individual analysis of mentioned enterprises in various time periods and compared group of one owner (organized as joint-stock company) with the enterprise of the other owner (organized as Limited Liability Company).

Using acknowledged analysis of the financial reports, which are basically functional relations between positions in Balance Sheet and Income Statement, we explore 
financial - economic condition and results in given enterprise.

Through parallel analysis of these enterprises, we have established what the real size of their assets is, in which way is company securing financing those assets and its profitability; to what degree of business and financial risk are companies exposed to; indicate future of the enterprises and recommendations to managers, owner, business partners and banks and what they can expect from each company. We have at our disposal financial data of these 5 companies from last 5 years.

\section{Methodology and Data Sources}

Literature review - As agricultural businesses today are becoming more complex, management needs to consider how its financial ratios play an important part in the health of its business. Financial analysis is an activity that includes the association between various accounts in financial statements as well as their measurement and interpretation (Sharifi, 2013).

There is no "universal" best methodology of the assessment of the economic viability of agricultural holdings. However, a combination of methodologies would result in a more efficient assessment of the economic viability of agricultural holdings, as that would include financial (Return on Equity, Material Investment, Cost, Subsidy, and Debt) and non-financial (Production Cost and Performance) indicators (Slavickiene, Savickiene, 2014).

The increased labor shortage and reduced profitability are growing concerns to the agricultural enterprises. Farm size is having positive association with the hired labor use and farm mechanization, but having negative association with family labor (Amarender, 2013). Some studies find that key drivers of net profit margins are education, farm size and typology, specialization, and level of government payments. Key factors affecting the asset turnover ratio component of the Du Pont model are age, contracting, specialization, and receiving government payments.

Key factors affecting asset-to-equity ratio component of the Du Pont model are farm size, farm typology, contracting, and specialization drive asset-to-equity ratio (Detre, Mishra, 2012). Profitability change can be decomposed into the product of total factor productivity (TFP) index and an index measuring changes in relative prices. Many TFP indexes can be further decomposed into measures of technical change, technical efficiency change, scale efficiency change and mix efficiency change (O’Donnell. 2012).

Returns on assets (ROA), a measure of financial performance widely used in the farm management literature, is the ratio of net farm income plus interest payment to total assets. ROA is widely hypothesized to be a function of farm's characteristics and management strategies used to manage the farm. Results from several studies show that although there is an inverted U-shaped relationship between age of the operator and financial performance, management strategies such as increasing the number of decision makers, engaging in value-added farming, and having a written business plan 
can lead to higher financial performance (Mishra, Wilson, Williams, 2009).

The results from some studies show that older farmers and larger farms are less likely to experience financial stress while hobby farms and livestock farms are more likely to experience financial stress. These results for beginning farmers indicate fewer significant effects (Katchova, 2010). The most significant determinants of financial stress are farmer's age, size of operation, ownership, year of operation, and farm type (D’Antoni, Mishra, Chintawar, 2009).

For the past decades, Serbian agriculture cannot keep pace with the agricultural development of the developed West European countries- neither in technical/ technological, nor organizational aspect. The same can be said of its overall efficacy and productivity. Consequences of a long-term disinvestment in the agricultural sector are more pronounced than ever (Babović, Veselinović, 2010). In the national economy clusters have been recognized as an instrument for strengthening productivity and innovation in small and medium Enterprises, as well as an instrument for regional development starting from 2005. Some researches show that clusters in Serbia were unable to develop until middle of 2013. They still possess low operative, innovative and export capacities, and there is a lack of key contributions of clusters to creating a unique regional specialization of labor and knowledge, as well as increasing regional competitiveness. In the future, cluster development in agribusiness will be directly related to the creation of a favorable business environment for SMEs, stimulating and predictable agricultural policy, as well as developed entrepreneurial initiatives aimed at joint activities and cooperation (Paraušić, Cvijanović, Mihailović, 2013).

Observing the current situation, credit support to the agriculture of Serbia through the banking sector is extremely unfavorable. Average active interest rates in Serbia are considerable higher than average active interest rates in the European Union and neighboring countries. Especially in times of global crisis, it is extremely important to provide more favorable credit conditions and thus stimulate taking loans for investments in agriculture. On the other hand, financial support to agriculture through the agrarian budget, even under more favorable credit conditions, is not enough for self-sustainability.

Lack of financial resources is a key limiting factor of the efficient utilization of agricultural resources - in transitional countries and developed ones alike. Despite the rich tradition and natural resources, the agriculture of Serbia is financially incapable of investing in new technologies, equipment, knowledge and innovations and, consequently, its competitiveness is seriously impaired, not only in international but domestic market as well. Surely, financial mix in the sector of agriculture is significantly different from the financial mix in other industries, due to certain specificities (Veselinović, Drobnjaković, 2014). The last step in ratio analysis is drawing conclusions about causes and consequences of liquidity "dry-ups", extreme liquidity, peak profitability, bottom-line profitability, slow and accelerated turnovers, and other aspect of "pyramid of financial indicators" (Malešević, 2013). 
According to some authors, the sensitivity analysis shows that the agricultural productivity is responsive to the increase of total operating costs, the decrease in average price, the decrease in total production, as well to the increase in the discount rate. Consequently, farmers should improve their equipment and allocate rationally the inputs to improve the profitability of agricultural investments (Maniriho, Bizoza, 2013).

\section{Financial report analysis}

In our financial analysis, we have used common methods and techniques for analyzing, namely: horizontal analysis, vertical analysis, ratio analysis, analysis of net working capital, debt ration analysis. Material assumptions of analyzes are based on providing usable data of the financial statements. Only usable financial statements are those which are free of bias and offer adequate basis for financial analysis. The accounting analysis is the analysis of historical data that financial analysis puts in relations to assess future trends in the company and ability to generate money.

It's important to determine:

1. Actual value of assets, that is, how much of Land, Building and Equipment actually belongs to owners and how much is still funded by another's resources.

2. Are company assets generating profit.

3. Is company exposed to financial risk in business.

4. Direct influences on enterprise profit as one of the basic tenets of its operations.

\section{Horizontal analysis}

In our research, we have conducted a comparative horizontal analysis of these enterprises basic categories of balance sheet and income statement for the past 5 years with special reference to the indicators for years 2012 and 2013. 
Table 1. Horizontal and vertical analysis of assets of the balance sheet

\begin{tabular}{|c|c|c|c|c|c|c|c|c|}
\hline \multicolumn{2}{|c|}{ ASSETS } & 2009 & $\begin{array}{l}\text { Vertical } \\
\text { analysis }\end{array}$ & 2012 & $\begin{array}{l}\text { Vertical } \\
\text { analysis }\end{array}$ & 2013 & $\begin{array}{l}\text { Vertical } \\
\text { analysis }\end{array}$ & $\begin{array}{l}\text { Horizontal analysis } \\
\qquad(2012 / 13)\end{array}$ \\
\hline \multirow{3}{*}{ 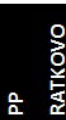 } & fixed assets & 1.058 .252 & $84,4 \%$ & 1.140 .432 & $73,1 \%$ & 1.113 .858 & $67,5 \%$ & $-26.574(-2 \%)$ \\
\hline & current assets & 182.808 & $14,6 \%$ & 377.436 & $24,2 \%$ & 502.588 & $30,4 \%$ & $125.152(33 \%)$ \\
\hline & total assets & 1.253 .371 & $100 \%$ & 1.559 .760 & $100 \%$ & 1.650 .319 & $100 \%$ & $90.559(6 \%)$ \\
\hline \multirow{3}{*}{ a } & fixed assets & 336.015 & $61,6 \%$ & 346.383 & $42,3 \%$ & 335.460 & $43,6 \%$ & $-10.923(-3 \%)$ \\
\hline & current assets & 209.530 & $38,4 \%$ & 473.244 & $57,7 \%$ & 434.787 & $56,4 \%$ & $-38.457(-8 \%)$ \\
\hline & total assets & 545.545 & $100 \%$ & 819.627 & $100 \%$ & 770.247 & $100 \%$ & $-49.380(-6 \%)$ \\
\hline \multirow[b]{3}{*}{ 응 朔 } & fixed assets & 521.994 & $70,7 \%$ & 419.333 & $56,2 \%$ & 420.014 & $57,5 \%$ & $681(0 \%)$ \\
\hline & current assets & 216.164 & $29,3 \%$ & 326.942 & $43,8 \%$ & 310.524 & $42,5 \%$ & $-16.418(-5 \%)$ \\
\hline & total assets & 738.158 & $100 \%$ & 746.275 & $100 \%$ & 730.538 & $100 \%$ & $-15.737(-2 \%)$ \\
\hline \multirow{3}{*}{ 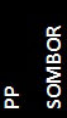 } & fixed assets & 246.713 & $41,9 \%$ & 166.603 & $22,5 \%$ & 162.569 & $23,6 \%$ & $-4.034(-2 \%)$ \\
\hline & current assets & 342.294 & $58,1 \%$ & 574.960 & $77,5 \%$ & 525.206 & $76,4 \%$ & $-49.754(-9 \%)$ \\
\hline & total assets & 589.007 & $100 \%$ & 741.563 & $100 \%$ & 687.775 & $100 \%$ & $-53.788(-7 \%)$ \\
\hline \multirow{3}{*}{$\begin{array}{l}\text { zo } \\
\text { Oे } \\
\text { o }\end{array}$} & fixed assets & 226.337 & $51,2 \%$ & 167.437 & $24,1 \%$ & 176.770 & $28,2 \%$ & $9.333(6 \%)$ \\
\hline & current assets & 215.564 & $48,8 \%$ & 528.368 & $75,9 \%$ & 449.863 & $71,8 \%$ & $-78.505(-15 \%)$ \\
\hline & total assets & 441.901 & $100 \%$ & 695.805 & $100 \%$ & 626.633 & $100 \%$ & $-69.172(-10 \%)$ \\
\hline
\end{tabular}

Source: Calculation of author

Table 2. Horizontal and vertical analysis of liabilities and equity of the balance sheet

\begin{tabular}{|c|c|c|c|c|c|c|c|c|}
\hline \multicolumn{2}{|c|}{ LIABILITIES \& EQUITY } & 2009 & $\begin{array}{l}\text { Vertical } \\
\text { analysis }\end{array}$ & 2012 & $\begin{array}{l}\text { Vertical } \\
\text { analysis }\end{array}$ & 2013 & $\begin{array}{l}\text { Vertical } \\
\text { analysis }\end{array}$ & $\begin{array}{l}\text { Horizontal analysis } \\
(2012 / 13)\end{array}$ \\
\hline \multirow[b]{3}{*}{ a } & capital & 1.172 .048 & $93,5 \%$ & 1.453 .201 & $93,2 \%$ & 1.574 .451 & $95,4 \%$ & $121.250(8 \%)$ \\
\hline & liabilities & 70.827 & $6,6 \%$ & 95.187 & $6,8 \%$ & 64.368 & $4,6 \%$ & $-30.819(-32 \%)$ \\
\hline & total L\&E & 1.253 .371 & $100 \%$ & 1.559 .760 & $100 \%$ & 1.650 .319 & $100 \%$ & $90.559(6 \%)$ \\
\hline \multirow[b]{3}{*}{ a $\bar{\Sigma}$} & capital & 186.872 & $34,3 \%$ & 259.553 & $31,7 \%$ & 357.201 & $45,4 \%$ & $97.648(38 \%)$ \\
\hline & liabilities & 358.673 & $65,7 \%$ & 560.074 & $68,3 \%$ & 413.046 & $54,6 \%$ & $-147.028(-26 \%)$ \\
\hline & total L\&E & 545.545 & $100 \%$ & 819.627 & $100 \%$ & 770.247 & $100 \%$ & $-49.380(-6 \%)$ \\
\hline \multirow{3}{*}{ ล 竞 } & capital & 289.291 & $39,2 \%$ & 193.865 & $26 \%$ & 212.678 & $29,1 \%$ & $18.813(10 \%)$ \\
\hline & liabilities & 448.867 & 60,8 & 552.410 & $74 \%$ & 500.625 & $68,5 \%$ & $-51.785(-9 \%)$ \\
\hline & total L\&E & 738.158 & $100 \%$ & 746.275 & $100 \%$ & 730.538 & $100 \%$ & $-15.737(-2 \%)$ \\
\hline \multirow[b]{3}{*}{$\therefore$ 용 } & capital & 356.530 & $60,5 \%$ & 473.799 & $63,9 \%$ & 496.211 & $72,1 \%$ & $22.412(5 \%)$ \\
\hline & liabilities & 232.477 & $39,5 \%$ & 267.764 & $36,1 \%$ & 191.564 & $27,9 \%$ & $-76.200(-28 \%)$ \\
\hline & total L\&E & 589.007 & $100 \%$ & 741.563 & $100 \%$ & 687.775 & $100 \%$ & $-53.788(-7 \%)$ \\
\hline \multirow{3}{*}{ 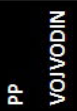 } & capital & 119.147 & $27 \%$ & 358.774 & $51,6 \%$ & 382.027 & $61 \%$ & $23.253(6 \%)$ \\
\hline & liabilities & 322.754 & $73 \%$ & 337.031 & $48,4 \%$ & 244.606 & $39 \%$ & $-92.425(-27 \%)$ \\
\hline & total L\&E & 441.901 & $100 \%$ & 695.805 & $100 \%$ & 626.633 & $100 \%$ & $-69.172(-10 \%)$ \\
\hline
\end{tabular}

Source: Calculation of author

PP Ratkovo fixed assets remained unchanged throughout the observation period, but the current assets increased through conversion of profit to current assets. Current assets increased the most in the enterprise Ratkovo Ltd. (by 33\%), while all enterprises of Agribusiness partner group recorded a fall, an average of 9.25\%.Fixed assets, in relation to year 2009, decreased in all companies of Agribusiness partner group and it is obvious that in the company PP Sombor in 2009 and 2010 there was a sale of part of fixed assets 
and converting to current (which resulted in lower income base). Positive changes in equity (capital) observed in the last two years have occurred in all companies.

The main difference in the operations of these enterprises in the period of the last two years has occurred with the liabilities of PP Ratkovo by managing to reduce its longterm liabilities by $59 \%$, and its short-term liabilities by $2 \%$, thus the company has strengthened its ownership structure and showed that its structure of fixed and current assets should be an example of management of agricultural enterprises.

Already in this comparative horizontal analysis of listed companies is obvious that the assets and liabilities increased at Ratkovo doo. Structure of sources is repaired and total enterprise value increased.

For enterprises of Agribusiness partner group, there was a positive change in the structures of the source of funds, but there has been a reduction in the overall value of the enterprise which is a negative trend, and therefore must be halted.

Table 3. Horizontal and vertical analysis of the income statement

\begin{tabular}{|c|c|c|c|c|c|c|c|c|}
\hline \multicolumn{2}{|c|}{$\begin{array}{c}\text { INCOME } \\
\text { STATEMENT }\end{array}$} & 2009 & $\begin{array}{l}\text { Vertical } \\
\text { analysis }\end{array}$ & 2012 & $\begin{array}{l}\text { Vertical } \\
\text { analysis }\end{array}$ & 2013 & $\begin{array}{l}\text { Vertical } \\
\text { analysis }\end{array}$ & $\begin{array}{c}\text { Horizontal analysis } \\
\text { (2012/13) }\end{array}$ \\
\hline \multirow{5}{*}{ 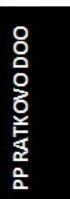 } & total revenue & 323.480 & $100 \%$ & 463.658 & $100 \%$ & 549.166 & $100 \%$ & $85.508(18 \%)$ \\
\hline & total expenses & 429.513 & $132 \%$ & 355.300 & $76,6 \%$ & 419.897 & $76,5 \%$ & $64.597(18 \%)$ \\
\hline & EBIT & -58.219 & 1 & 102.619 & $22,1 \%$ & 125.819 & $22,9 \%$ & $23.200(23 \%)$ \\
\hline & EBITDA & -33.709 & I & 139.623 & $30,1 \%$ & 171.931 & $31,3 \%$ & $32.308(23 \%)$ \\
\hline & net income & -98.570 & 1 & 108.358 & $23,4 \%$ & 121.251 & $22,1 \%$ & $12.893(12 \%)$ \\
\hline \multirow{5}{*}{ 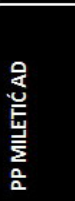 } & total revenue & 531.674 & $100 \%$ & 377.491 & $100 \%$ & 508.408 & $100 \%$ & $130.917(35 \%)$ \\
\hline & total expenses & 503.933 & $94,8 \%$ & 324.284 & $85,9 \%$ & 411.577 & $80,1 \%$ & $87.273(27 \%)$ \\
\hline & EBIT & -106.473 & I & 64.043 & $17 \%$ & 102.771 & $20,2 \%$ & $38.728(60 \%)$ \\
\hline & EBITDA & -91.479 & 1 & 78.561 & $20,8 \%$ & 115.363 & $22,7 \%$ & $36.802(47 \%)$ \\
\hline & net income & 27.741 & $5,2 \%$ & 53.207 & $14,1 \%$ & 96.851 & $19 \%$ & $43.644(82 \%)$ \\
\hline \multirow{5}{*}{ 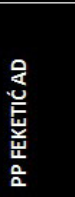 } & total revenue & 224.266 & $100 \%$ & 312.290 & $100 \%$ & 394.411 & $100 \%$ & $82.121(26 \%)$ \\
\hline & total expenses & 315.417 & $140 \%$ & 284.915 & $91,2 \%$ & 375.598 & $95,2 \%$ & $90.683(32 \%)$ \\
\hline & EBIT & -59.725 & 1 & 16.578 & $5,3 \%$ & 26.415 & $6,7 \%$ & $9.837(59 \%)$ \\
\hline & EBITDA & -41.183 & I & 29.291 & $9,4 \%$ & 56.409 & $14,3 \%$ & $27.118(93 \%)$ \\
\hline & net income & -91.151 & 1 & 27.375 & $8,7 \%$ & 18.813 & $4,8 \%$ & $-8.562(-31 \%)$ \\
\hline \multirow{5}{*}{ 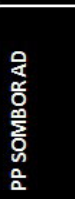 } & total revenue & 643.480 & $100 \%$ & 346.858 & $100 \%$ & 245.034 & $100 \%$ & $-101.824(-29 \%)$ \\
\hline & total expenses & 591.744 & $91,9 \%$ & 344.456 & $99,3 \%$ & 217.998 & $88,9 \%$ & $-126.458(-37 \%)$ \\
\hline & EBIT & -20.051 & I & 40.528 & $11,7 \%$ & 35.947 & $14,7 \%$ & $-4.581(-11 \%)$ \\
\hline & EBITDA & -6.679 & 1 & 48.950 & $14,1 \%$ & 43.220 & $17,6 \%$ & $-5.730(-12 \%)$ \\
\hline & net income & 17.978 & $2,8 \%$ & 2.104 & $0,6 \%$ & 22.412 & $9,1 \%$ & $20.308(965 \%)$ \\
\hline \multirow{5}{*}{ 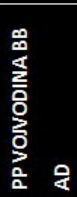 } & total revenue & 255.737 & $100 \%$ & 254.092 & $100 \%$ & 262.370 & $100 \%$ & $8.278(3 \%)$ \\
\hline & total expenses & 262.584 & $102 \%$ & 247.500 & $97,4 \%$ & 237.989 & $90,7 \%$ & $-9.511(-4 \%)$ \\
\hline & EBIT & -61.758 & 1 & 16.087 & $6,3 \%$ & 28.070 & $10,7 \%$ & $11.983(74 \%)$ \\
\hline & EBITDA & -56.764 & I & 20.407 & $8 \%$ & 32.787 & $12,5 \%$ & $12.380(61 \%)$ \\
\hline & net income & -6.847 & 1 & 5.876 & $2,3 \%$ & 23.253 & $8,9 \%$ & $17.377(296 \%)$ \\
\hline
\end{tabular}

Source: Calculation of author 
In the Horizontal analysis of the Income Statement of listed companies in addition to the basic categories of total revenue and total expenditure and hence achieved net profit we have included two additional indicators of business performance EBIT and EBITDA.

This indicator (EBIT) tells us about earning power of company and therefore we gave this indicator special emphasis so we could recognize within observed agricultural companies of primary agricultural production location where a fundamental difference in the achievement levels of corporate profits emerge.

In our study, special attention was paid to finding the cause of achieving different levels of profit in the observed company.

All considered enterprises are 2009 years before the takeover by the current owners had negative EBIT and EBITDA. Over the years earnings involvement in operating income has increased but not in proportion and not as progressive within all surveyed companies.

In order to accurately conclude the reasons for the EBIT and EBITDA different trends and different involvement in operating income, we did percentage involvement of material costs compared to operating income and the impact of the cost of wages salaries and other personal expenses compared to total income.

Enterprise PP Ratkovo succeeded to convert negative EBIT (-21\%) from2009 into a stable positive EBIT margin of $23 \%$ in both 2012 and 2013 which at the moment can be called the most desirable margin in ordinary course of business in agriculture and especially when you add to that the company did a serious depreciation of existing assets in the last two years, which allowed EBITDA to reach $32 \%$; this can be treated as a model for other companies observed categories. Share of material costs in operating income was 48\% in 2009 and then recorded a steady decline with 34\% in 2012 down to $29 \%$ in 2013 which can be considered as an ideal material share of production costs in agricultural production. The share of wage costs decreased from $22 \%$ in 2009 to $12 \%$ in 2012 and in 2010 to an amazing 10\%. These are remarkable results of operations aimed at realizing a large profit from continuing operations of agricultural enterprises. Within enterprises of Agribusiness partner group situation has also improved, but not nearly as in PP Ratkovo.

If we know that the share of wages in operating income of PP Ratkovo is $10 \%$ it is difficult to comment on the share of wages in total income of $28 \%$ (which is average of the group) and it is certain that this cannot be a long-term sustainable category. Certainly in the material cost and in payroll expenses Agribusiness partner group must react quickly and reduce this share, or absolutely redact these categories or increase business revenue.

An additional space for improvement in addition to this reduction could be found in the reduction of other operating expenses and the acquisition value of the sold goods since it is apparent that the enterprise is engaged in transit goods sales beside primary production. 


\section{Vertical analysis}

Vertical analysis of structure of assets in companies PP Ratkovo doo shows fixed assets is in 2012 as $73.1 \%$ and in the year $201367.5 \%$ of the total assets. By increasing current assets, company Ratkovo doo defines its asset structure in such a way that it brings the greatest profit. Within company PP Miletić property and PP Feketić share of fixed assets in the overall structure of the active can be considered theoretically stable while in the companies PP Sombor and PP Vojvodina, where the structure of assets increases the share of fixed assets but in the final structure for the reporting year reached only $23 \%$ involvement, which means that these companies deal, in addition to primary production, with trading activities.

In the liabilities and equity structure of the PP Ratkovo capital is $95.4 \%$ in 2013 which means that all of fixed assets are covered from own resources (capital) and they are indeed the owners of the resources and here are current assets covered by long-term sources and this strives to an ideal structure. PP Ratkovo can be seriously indebted and get into a serious investment, since it does not rely on business partners. In the companies of Agribusiness partner group the situation is worse and could be defined in the following way.

In the company PP Miletić capital in 2012 had a share in total liabilities of $31.7 \%$ and in 2013 structure had positive changes despite the decrease in total liabilities, share capital increased to $47.2 \%$. It is clear that there is the great dependence in company PP Miletic to suppliers and other creditors, but the company has a good tendency and rapid ability to adapt to this structure so that it can generate maximum profits.

In enterprise PP Feketić situation is drastically worse - share of capital in total assets structure is increased from $26 \%$ to $29.1 \%$, but this is too low level of capital. The company is affected by the pressure of suppliers and other creditors and this drastically affects the performance of the company. Business owners do not own even $30 \%$ of the total value and the company must take urgent actions to stabilize the situation. If we add to this that from its own assets and long-term liabilities company does not cover the fixed assets but instead have used credits from the costly short-term sources, it is clear that these categories have drastic effect on the level of operating costs and thus on generating healthy profit level in company.

For enterprise PP Sombor and PP Vojvodina situation is more stable. Fixed assets are covered by their own capital (golden rule) and therefore created the opportunity for increased profitability. The structure of the sources is stable and allows the owners of a lot of security in enterprise management.

For enterprise PP Vojvodina Bački Brestovac share of capital in the structure of funding sources has also increased over the last two years. If we add that fixed assets are fully covered by this, we see that the structure gained a particular security. Comment in the last two observed companies is that, in our opinion, in agriculture the primary agricultural production, share of fixed assets in the total assets of the enterprise is 
low. The two enterprises, based on structure of assets, looks more like a trade sized enterprises than on enterprises with primary agricultural production in their own areas.

In the observed companies short-term liability share is too high and that means that companies are operating under very expensive market conditions because is funded with short-term sources. In the vertical analysis of the income statement we should put all elements (cost of goods sold, profit, net profit, general expenses) in relation with the value of the total revenue.

Total expenditure and net income does not make total revenue in our table because we haven't show the category of income taxes.

\section{Ratio analysis}

It's important to determine aim of the analysis in which indicators will have purpose. In analysis of the financial reports through ratio indicators standards which are used are: knowledge and experience of the analyst, comparison of the branch average values, historical data and comparison of planned values with determined standards.

The emphasis is on the comparative analysis where will be used: liquidity ratio, debt ratio, activity ratio, profitability ratio. All analysis is for the purpose of perception of their importance for achieving the best results for observed companies.

\section{Liquidity ratio}

Liquidity indicators are intended to show the company's ability to service its payment obligations to pay, while maintaining the necessary structure of assets and the preservation of good credit solvency.

Table 4. Liquidity ratio

\begin{tabular}{|llllll|}
\hline Liquidity ratio & $\mathbf{2 0 0 9}$ & $\mathbf{2 0 1 0}$ & $\mathbf{2 0 1 1}$ & $\mathbf{2 0 1 2}$ & $\mathbf{2 0 1 3}$ \\
\hline PP Ratkovo doo & 2,58 & N/D & 7,45 & 8,48 & 11,46 \\
\hline PP Miletić ad & 0,63 & 0,73 & 0,74 & 0,84 & 1,05 \\
\hline PP Feketić ad & 0,50 & 0,51 & 0,56 & 0,74 & 0,78 \\
\hline PP Sombor ad & 1,61 & 2,13 & 1,70 & 2,15 & 3,05 \\
\hline PP Vojvodina BB ad & 0,67 & 1,43 & 1,64 & 1,59 & 1,86 \\
\hline
\end{tabular}

Source: Calculation of author

Enterprise PP Ratkovo has increased from 2009 almost 5 times current ratio and now is five times higher than normal ratio; it is obvious that company is able to fully manage its liquidity and to settle all obligations on time to its creditors so they do not have to worry about the claims settlement. PP Ratkovo achieves best market conditions and creditworthiness and thus has a very positive effect on reducing production costs and other costs and increase profits.

For enterprises PP Miletić situation is drastically different, even though ratio has tendencies of growth it is still on the level where the company has difficulties to pay 
its obligations and where suppliers are using stronger prices trying to compensate for uncertainty in the collection of receivables, so the company does not have the ability to realize additional benefits in the market resulting from the stable liquidity.

PP Feketić has major liquidity problems with the settlements to suppliers and creditors. Fact that only $78 \%$ of its short-term obligations can pay from its own funds indicates that at any moment it can block the accounts of companies that do not meet its obligations. Its protective factor is the size of the group, because with such liquidity company can't maintain regular work for long.

Company PP Sombor in last two years has a stable liquidity ratio that meets defined norms and far above the average of the group in which it operates. It has a potential to be a carrier of the market withdrawal group and try to achieve basic market conditions at the supplier.

PP Vojvodina in the last five periods of the observed time span has improved overall liquidity ratio, and in that light advice would be to make procurements through group carrier which would improve its market position as well as profitability. To be even safer in the liquidity of these companies we will implement more stringent test.

\section{Quick (acid test) ratio}

For enterprise PP Ratkovo fast current ratio is above the normal limits and even records very distinct growth in the last two years. This fact gives the company a great maneuver market space and the opportunity at any time to obtain all the materials and necessary working capital in order to achieve the best possible profit.

Table 5. Quick (acid test) ratio

\begin{tabular}{|llllll|}
\hline Quick ratio & $\mathbf{2 0 0 9}$ & $\mathbf{2 0 1 0}$ & $\mathbf{2 0 1 1}$ & $\mathbf{2 0 1 2}$ & $\mathbf{2 0 1 3}$ \\
\hline PP Ratkovo doo & 1,27 & N/D & 4,27 & 4,88 & 7,52 \\
\hline PP Miletić ad & 0,41 & 0,50 & 0,61 & 0,72 & 0,76 \\
\hline PP Feketić ad & 0,26 & 0,34 & 0,43 & 0,56 & 0,56 \\
\hline PP Sombor ad & 1,15 & 1,91 & 1,52 & 2,06 & 2,78 \\
\hline PP Vojvodina BB ad & 0,46 & 1,28 & 1,49 & 1,48 & 1,60 \\
\hline
\end{tabular}

Source: Calculation of author

On the other hand the companies in Agribusiness partner situation are very similar with previous general liquidity ratios and companies are denied the opportunity to achieve additional financial benefits on the market. Enterprises PP Sombor and PP Vojvodina Bački Brestovac have very fair quick ratio while in the company PP Miletić and PP Feketić quick liquidity ratio indicates that the companies are in the current liquidity problems and that can cause extension in settling obligations to suppliers which has consequences on the income statement and increasing costs. 
Looking into the company's liquidity through the liquidity ratio it is obvious that all companies are not the same and various analysts perceive this ratio differently which affects companies profitability directly and indirectly.

1. PP Ratkovo leads good policy of its own liquidity. In companies PP Sombor $\mathrm{i}$ Vojvodina BB indicators are at the level of the prescribed standards of business and enterprises PP Miletic should change their structure of short-term liabilities into long-term and PP Feketić must increase capital in relation to obligations thus provide the company long-term or own sources of funding because its solvency is threatened and thus profitability.

2. Owners of company PP Ratkvo are satisfied, the company will operate without the liquidity problems, PP Ratkovo has favorable conditions for the development. Enterprises PP Sombor and PP Vojvodina BB situation is that companies can operate regularly without any particular problems with liquidity. Company PP Feketić must immediately modify the liquidity policy and owners must add their own capital or establish partnership with someone who will do it. At PP Miletić enterprises owners and management must conduct restructuring by converting part of the short-term liabilities into long-term.

3. Creditors and business partners companies PP Ratkovo do not have to worry about their claims - they will be paid in full amount, while creditors of Agribusiness partner groups must decide to collect receivable payments in a way that does not jeopardize liquidity of companies. From PP Sombor and PP Vojvodina it can be expected to pay with some degree of delay while in the PP Miletić and especially PP Feketić receivables can be collected through compensation, assuming the claims, assignment etc.

4. Banks will without trouble offer liquidity loans and investments to the company PP Ratkovo while enterprises in Agribusiness groups will have to be considered together and as such be treated with careful defined credit policy, which will certainly have a price.

\section{Debt ratio}

PP Raktovo is financed with its own capital. Company PP Miletić in 2009 had a share of liabilities of $65 \%$ and in the selected period managed to reduce it to $54 \%$. The company PP Fektetic has a substantial share of liabilities in total assets. The share of liabilities in the overall structure of the source has a market price which directly affects the profitability of the company. In enterprises PP Sombor and PP Vojvodina BB there has been a reduction in liabilities and total debt went in PP Sombor from 39\% in 2009 to $28 \%$ in 2013 . In the company PP Vojvodina ratio dropped from $73 \%$ in 2009 to $39 \%$ in 2013 . 


\section{Time repayment obligation}

One of the key issues in any business enterprise is how much time it takes to pay off all existing debts and it is calculated as the period of repayment.

If it is greater than 4 , or if you need more than four years to pay off the debts, the management in company must respond and must reduce obligations or increase EBITDA, which means that it must increase profitability by reducing costs or increasing revenues by using the same capacity.

Using EBITDA in relation to total liabilities for PP Rakovo it takes only 5 months; for PP Miletić is a necessary period of 3.5 years which is also very acceptable. In PP Sombor necessary period to settle all obligations is 4.5 years which can also be considered acceptable while the PP Vojvodina required period of 7.5 year which is not good and should react. On the other hand PP Feketic need more than 9 years, which is an alarming situation and in case that does not respond quickly or add their own capital which would settle the obligation, or increase EBITDA enterprise will fall into existential problems.

\section{Activity ratio}

Indicators of asset turnover ratio shows that the company PP Ratkovo less efficiently invests business asset and that every penny invested in operating assets generate smaller revenues from sales. In enterprises of Agribusiness group explanation can be easily found by looking at the structure of company's property or perhaps ways of valorization fixed assets through accounting.

To be able to make clearer conclusions about the effectiveness of doing business we will look at turnover ratio of inventories to determine whether the physical inventory increase was caused by financial conceived project management, attempts to influence the operating results or the inability realization of inventories. In the company PP Ratkovo it's obvious that they control turnover and time of inventory sales which results in reduction of total turnover but increase in profitability.

To be able to fully comment on the inventory turnover we will also look and how many days are stocks related (days in inventory)

Inventory turnover ratio and days in inventory is certainly different and we will comment in such matter considering we are dealing with agricultural enterprises engaged in primary agricultural production and other businesses. It is a known fact that rates of inventory turnover and the less number of days in inventories period are recommendations of good practice. But in our case, we start from the following facts.

These are enterprises of the agricultural sector, which has a long production cycle and the specific purchase of agricultural products at the end of the production cycle. Selling products at this time will achieve the best turnover ratio but the question is whether it achieves the best prices. Profit and profitability of agricultural enterprises may tell us that the sale of its finished products most important category for profits in agricultural enterprises. 
Since in out observed companies an example of PP Ratkovo show us that it has the best structured sources of funds with which generates the best financial results but has worst asset turnover ratio, but also has good days in inventory at 249 days, which means that it can choose moment of sales for its finished products and thus making the best results. Looking at businesses in Agribusiness partner group we can see that they do not have overall control of the moment of selling their products but rather sell them when they have to repair liquidity but this does not create best market conditions which directly influence the profitability and level of income.

Table 6. Inverse proportion between turnover ratio of inventories, EBIT and EBITDA, profit margin and ROA

\begin{tabular}{|c|c|c|c|c|c|c|}
\hline & $\begin{array}{c}\text { Turnover } \\
\text { ratio of } \\
\text { inventories }\end{array}$ & $\begin{array}{l}\text { Days in } \\
\text { inventory }\end{array}$ & $\begin{array}{c}\text { EBIT } \\
\text { margin }\end{array}$ & $\begin{array}{l}\text { EBITDA } \\
\text { margin }\end{array}$ & $\begin{array}{l}\text { Profit } \\
\text { margin }\end{array}$ & ROA \\
\hline \multicolumn{7}{|l|}{2013} \\
\hline PP RATKOVO & 1,47 & 249,14 & 23,40 & 31,97 & 24,18 & 7,55 \\
\hline PP MILETIĆ & 3,51 & 103,87 & 20,50 & 23,01 & 30,02 & 12,18 \\
\hline PP FEKETIĆ & 3,43 & 106,38 & 6,87 & 14,68 & 6,92 & 2,55 \\
\hline PP SOMBOR & 4,91 & 74,28 & 14,97 & 18,00 & 12,41 & 3,14 \\
\hline PP VOJVODINA & 2,82 & 129,49 & 12,00 & 14,02 & 14,41 & 3,52 \\
\hline \multicolumn{7}{|l|}{2012} \\
\hline PP RATKOVO & 1,63 & 224,04 & 23,46 & 31,92 & 26,86 & 7,17 \\
\hline PP MILETIĆ & 3,68 & 99,13 & 17,35 & 21,28 & 18,63 & 6,66 \\
\hline PP FEKETIĆ & 2,92 & 125,16 & 6,16 & 10,88 & 13,23 & 3,70 \\
\hline PP SOMBOR & 3,18 & 114,76 & 12,45 & 15,04 & 0,73 & 0,26 \\
\hline PP VOJVODINA & 3,02 & 120,91 & 7,08 & 8,98 & 2,79 & 0,85 \\
\hline \multicolumn{7}{|l|}{2009} \\
\hline PP RATKOVO & 2,73 & 133,87 & $-21,71$ & $-12,57$ & $-38,62$ & $-7,54$ \\
\hline PP MILETIĆ & 3,98 & 91,69 & $-29,58$ & $-25,41$ & 7,99 & 5,00 \\
\hline PP FEKETIĆ & 2,15 & 169,88 & $-29,81$ & $-20,56$ & $-47,19$ & $-12,34$ \\
\hline PP SOMBOR & 4,31 & 84,62 & $-3,63$ & $-1,21$ & 3,51 & 3,14 \\
\hline PP VOJVODINA & 2,90 & 125,76 & $-34,66$ & $-31,86$ & $-3,83$ & $-1,73$ \\
\hline
\end{tabular}

Source: Calculation of author

\section{Accounts receivable collection period (day's sale outstanding)}

This indicator shows in which period the claims are collected from suppliers and when you compare that with days in inventory and billing of customers we can see it from whose funds the company is mainly funded during the year.

If that is put in relation with the number of days in the year, we can see that the company PP Ratkovo accelerates payments of their claims so during the last two years with 114 days dropped to 67 . 
In companies of Agribusiness partner groups, we can conclude that there are major problems in collecting receivables. The company PP Miletic debt collection with more than one year decreased to 296 days, which is stable in the group, but this collection is not recommended. Other group companies have even less turnover ratio of suppliers so that in the PP Sombor in 2013 it is 811 days, which means compensation were made but were not implemented or company doesn't have control in debt collection. I think companies of Agribusiness partner groups must absolutely consider the business of the whole group in the collection of receivables as well as booking of these data, because at the current state it creates impression that they don't have the control in the collection of receivables and thus the impact on liquidity and profitability.

\section{Profitability ratio}

Gain and loss are the result from the commitment and sources of funding. If the means and resources are used efficiently the firm is making a profit if you do not there is business loss. When the profit (in case of we do not have anything to interpret) is put in relation with the resources that are engaged in their creation we can get different indicators of profitability. Some researchers recommend that corporate entities should not pursue extreme liquidity policies at the expense of their profitability, i.e. they should strike a balance between the two performance indicators (liquidity and profitability) (Chukwunweike, 2014).

Having reflected upon indebtedness impact on the profitability of domestic companies prior to and after the financial crisis, some authors concluded that the impact of financial leverage on the business results had continuously been diminished. In order to avoid over-indebtedness, companies are forced to reduce financial leverage, which influences a considerable fall in profitability (Račić, Barjaktarović, Zeremski, 2011).

\section{Profit margin}

The examples above show that the agricultural activity of primary agricultural production, depending on harvest and price, profit margin can be very stable category.

In the example of PP Ratkovo profit margin of negative trend, i.e. great loss in 2009, but managed to regain stable profit margin at the level of $26.8 \%$ and $24.2 \%$ achieved in the last two observed years of business and that demonstrates that the company is working very well and making a profit.

In the case of PP Miletić, we can say that in the last two years profit margin also stabilized and reached a certain average, and that at this rate firm may continue to work and in the coming period it will remove all the problems addressed in the structure of sources and create a considerable profit.

For enterprises PP Fektetić negative profit margin was also recorded in 2009 and 2010 and even after that company failed to achieve an adequate financing structure and the production costs are so great that brings presence of company in the appropriateness 
of the profit margin of $6.9 \%$ in 2013 in agricultural production, therefore the company cannot move forward.

PP Sombor also cannot stabilize their profit margin, and must identify objective reasons for such business as it seriously deviates from the average of both companies in group and in comparison with stable PP Ratkovo.

PP Vojvodina has the possibility of adjusting the input and output categories to stabilize the business and improve its profit margins, which in the last two years shows that there has been progress, but not enough for such an enterprise.

\section{Return on assets (roa)}

Company PP Ratkovo has a stable rate of return on business assets- over the past two years ROA has stabilized at over 7\% while the at Agribusiness partner group positive influence has occurred in the company PP Miletić, which in the past two years has stabilized rate of return on operating assets, while in other companies from the group, this rate of growth is not enoughand would have to stabilize it in the future.

\section{Return on equity (roe)}

Is also one of the important indicators of the profitability of the company and refers to the yield of own capital (equity).

In our case, it is very important to remember the indicators of financing, and that can tell us that PP Ratkovo has share of capital in the financing of 95\% in 2013 which effects on roa realistic projection.

\section{Conclusion}

1. Through comparative financial analysis of five surveyed companies of the same branch and activities with practical application of methods and techniques we concluded that all of the techniques in its domain indicated that the company PP Ratkovo operates more stable and closer to the anticipated standard and each element has better indicators than enterprises in Agribusiness partner group. Through horizontal and vertical analysis, it was concluded that companies use expensive external sources of funding. We have precisely defined in which part of the cost the largest differences occur and what are optimal days in inventory which affects directly profitability of the agricultural companies.

2. Companies in Agribusiness group, in order to have a clear situation and could keep track of the business, each of them must cleanse internal relations with mutual posting and revaluation of fixed assets as they should be aware that the balance sheet and income statement are public available categories and that each analyst has access to their financial reports. To improve profitability we must conduct financial consolidation for companies in the field of source changes and funding structures, eventually delayed at which we individually defined for each enterprise. 
The company PP Miletic should at least change the structure of the short-term obligations and commitments and turn into a long-term under favorable conditions. Company PP Feketić should make a specific plan of reorganization. Situation could lead to the point where the other firm or the owners have to save this enterprise with recapitalization. In PP Sombor it is essential to stop the decrease in assets and stabilize the situation between fixed and current assets because it is obvious that the PP Sombor trade most of all members in Agribusiness partner group. PP Vojvodina Bački Brestovac has good conditions to conduct positive business in the future period to compensate for declining assets.

3. In this research, the author has proved the general and partial hypothesis. A general assessment of five choosen agricultural companies was conducted, and then, their financial performance was analyzed using Financial Statement Analysis, Percentage Method, Trend Analysis and Ratio Analysis techniques with the aid of financial statement for the period of 2009-2013. Financial analysis is an indispensable part of the decision making process in agriculture, but adequate interpretation of the obtained results is only possible in the proper context (it is necessary to take into account the specific characteristics of agriculture). It is also necessary to take into account the historical data limitations.

\section{References}

1. Agencija za privredne registre (2014, December 24), available on: http://www.apr. gov.rs.

2. Amarender, R. (2013): Farm profitability and Labor Use Efficiency, Indian Journal of Dry land Agricultural Research Development, Vol. 28 No. 2, pp. 1-21.

3. Babović, J., Veselinović, B. (2010): Agrarna politika EU i prilagođavanje agrara Srbije, Zbornik radova, Društveni izazovi evropskih integracija - Srbija i uporedna iskustva, Fakultet za pravne i poslovne studije, Novi Sad, Srbija, ISBN 978-86515-0556-3, pp. 195-206.

4. Chukwunweike, E. (2014): The Impact of Liquidity on Profitability of Some Selected Companies: The Financial Statement Analysis (FSA) Approach, Research Journal of Finance and Accounting, Vol. 5 No. 5, pp. 81-90.

5. Detre, D., Mishra, A. (2012): Drivers of agricultural profitability in the USA: An application of the Du Pont expansion method, Agricultural Finance Review, Vol. 72 No. 3, pp. 325-340.

6. D’Antoni, J., Mishra, A., Chintawar, S. (2009). Predicting Financial Stress in Young and Beginning Farmers in the United States, Southern Agricultural Economics Association, Annual Meeting, Atlanta, Georgia, available at: http:// ageconsearch.umn.edu/bitstream/46861/2/Predicting\%20Financial $\% 20$ Stress $\% 20$ in $\% 20$ Young\%20and\%20Beginning\%20Farmers.pdf.

7. Investiciono-razvojni fond Crne Gore (2014, December 24), available on: http:// www.irfcg.me. 
8. Katchova, A. (2010): An Analysis of the Financial Performance of Beginning Farmers, Agricultural and Applied Economics Association, Annual Meeting, Denver, Colorado, available at: http://ageconsearch.umn.edu/bitstream/61513/2/ katchova.pdf.

9. Malešević, Đ. (2013): The relevance of ratio analysis for the purposes of decision making on liquidity and profitability, Računovodstvo, Vol. 57 No. 5-6, pp. 38-50.

10. Maniriho, A., Bizoza, A. (2013): Financial Benefit-Cost Analysis of Agricultural Production in Musanze District (Rwanda), Academia Arena, Vol. 5, No. 12, pp. 30-39.

11. Mishra,A., Wilson, C., Williams, R. (2009): Factors affecting financial performance of new and beginning farmers, Agricultural Finance Review, Vol. 69 No. 2, pp. 160-179.

12. Narodna banka Srbije (2014, December 24), available on: http://www.nbs.rs/ internet/cirilica/67/pn.html.

13. O’Donnell, C. (2010): Measuring and decomposing agricultural productivity and profitability change, Australian Journal of Agricultural and Resource Economics, Vol. 54 No. 4, pp. 527-560.

14. Paraušić, V., Cvijanović, J., Mihailović, B. (2013): Market analysis of clusters in Serbian agribusiness, Ekonomika poljoprivrede, Vol. 60, No. 4, pp. 713-728.

15. Račić, Ž., Barjaktarović, L., Zeremski, A. (2011). Analysis of indebtedness impact on the profitability of successful domestic companies in the financial crisis, Industrija, Vol. 39, No. 3, pp. 45-60.

16. Ranković, J. (2004): Upravljanje finansijama preduzeća, Proinkom, Beograd.

17. Sharifi, O. (2013): Financial Management and Ratio Analysis for Agricultural Cooperatives, Global Journal of Commerce \& Management Perspective, Vol. 2 No. 4, pp. 127-133.

18. Slavickiene, A., Savickiene, J. (2014): Comparative Analysis of Farm Economic Viability Assessment Methodologies, European Scientific Journal, Vol. 10, No. 7, pp. $130-150$.

19. Veselinović, B., Drobnjaković, M. (2014): Qualitative and quantitative analysis of micro and macro aspects of agricultural finance, Economics of Agriculture, Vol. 61, No. 3, pp. 771-786.

20. Veselinović, B., Vunjak, N. (2014): Poslovne finansije - teorija i praksa, Drugo izdanje, Fakultet za ekonomiju i inženjerski menadžment, Novi Sad, Srbija. 


\title{
UZROCI RAZLIČITE PROFITABILNOSTI POLJOPRIVREDNOG SEKTORA
}

\author{
Branko Vučković
}

\begin{abstract}
Abstrakt
Identifikacija razloga različite profitabilnosti u sektoru primarne polljoprivredne proizvodnje urađena na studiji slučaja skoro identičnih poljoprivrednih preduzeća. Dokaz da finansijski mix i u okviru sličnih poljoprivrednih preduzeća dovodi do različite profitabilnosti.

Uporednom finansijskom analizom pet posmatranih preduzeća iste grane, delatnosti $i$ praktičnom primenom metoda $i$ tehnika smo konstatovali da su sve tehnike $u$ svom domenu ukazivale da jedno preduzeće, PP Ratkovo, posluje stabilnije i bliže predviđenim normama $i$ u svakom elementu ima bolje pokazatelje od druge grupe preduzeća. Horizontalnom i Vertikalnom analizom je konstatovano da preduzé́a Agribusines partner group koristi skupe tuđe izvore finansiranja. Precizno smo definisali u kom segmentu troškova se javljaju najveće razlike i koji su razlozi da PP Ratkovo u poslednje dve godine ispolji odličnu profitabilnost, merenu po svim kriteijumima, EBIT, EBITDA, NETO DOBIT, kao i odličnu stukturu materijalnih troškova i troškova plata u okviru poslovnih prihoda i razloge zašto to nisu uradila preduzeća Agribusines partner group.
\end{abstract}

Ključne reči: Profitabilnost, Poljoprivredni sektor, Finansijska analiza.

2 Mr Branko Vučković, Vojvođanska banka - NBG Group, direktor poslovnog centra Severna Vojvodina, Ulica Banatska br. 24, 25000 Sombor, Telefon: +381 648960 025, E-mail: vule.sombor@gmail.com

EP 2016 (63) 1 (123-141) 